\title{
A systematic survey of plant biodiversity study within the land of Institut Teknologi Sumatera (ITERA)
}

\author{
I Oktaviani*, M Asril, Y Aryanti, and S S Leksikowati \\ Department of Biology, Institut Teknologi Sumatera, Jalan Terusan Ryacudu, Way Hui, Jati \\ Agung, South Lampung - 35365 \\ *indah.oktaviani@bi.itera.ac.id
}

\begin{abstract}
The conversion of agricultural land and plantation into an area with high human activity can affect the biodiversity contained in it. The biodiversity of a region can be surveyed and collect in a systematic database to know the wealth of flora and fauna resources within a certain period of time. The aim of this research is to identify and inventory the vegetation database of plant, which can then be used as one of the important information related to the environmental change that happened from time to time following the impact of the growing development expansion. This study was conducted within the campus of the Institut Teknologi Sumatra (ITERA) which is undergoing physical construction in the form of buildings, roads, and some retention basin. Data retrieval was done by direct observation using the cruising method. The observations of each species are documented, identified, recorded and arranged in the collection catalog.
\end{abstract}

\section{Introduction}

Biodiversity is often used as a measure of the health of an existing biological system. It can scientifically be grouped according to the scale of biological organization, starting from genes, plant species, animals, and microorganisms as well as ecosystems and ecological processes of where this form of life is being a part of. Using ecological studies about how an organism can live and coexist in the area by considering its environmental conditions we can measure the value, threats, and benefits of biodiversity conservation [1]. There is a relationship of interdependence between biotic factors and a combination of factors that influence the population of species in the region [2]. Tropic regions have environmental conditions that are able to provide high environmental carrying capacity so that more species can live in the area. Conversely, the disturbed area will experience a narrowing of resources and this has been studied to have an impact on the decline in species composition of the organism [3,1]. The value of biodiversity in some area are fundamental to identify, related to the conservation planning such as landscape management, which its relative costs and benefits can be overlap $[4,5]$.

Population growth in Indonesia is directly proportional to the pace of development. The increasing development has resulted in a decrease of species diversity [6]. The initial phase of development began with the opening of large areas of forest into monoculture and settlement plantations [7]. South Lampung region, including the Institut Teknologi Sumatera (ITERA) campus area is undergoing rapid development, making it unable to avoid the change of land use into monoculture and settlement plantations. The development progress often carried out without regard to environmental disturbance caused by the changing environment. In addition, the management of forest space is converted into 
settlements and plantations without prior calculation. Based on this fact, preliminary research is needed to identify and inventory a database of plant vegetation on the ITERA campus to fit the concept of greenways, green networks, green infrastructure, and ecological networks to bridge development together with nature conservation activities. This is also in line with the development concept of Smart, Friendly, and Forest Campus owned by ITERA.

\section{Methods}

\subsection{Study Area}

The research location was located in the land owned by Institut Teknologi Sumatera (ITERA) campus land, Jati Agung, Lampung, Indonesia (figure 1).

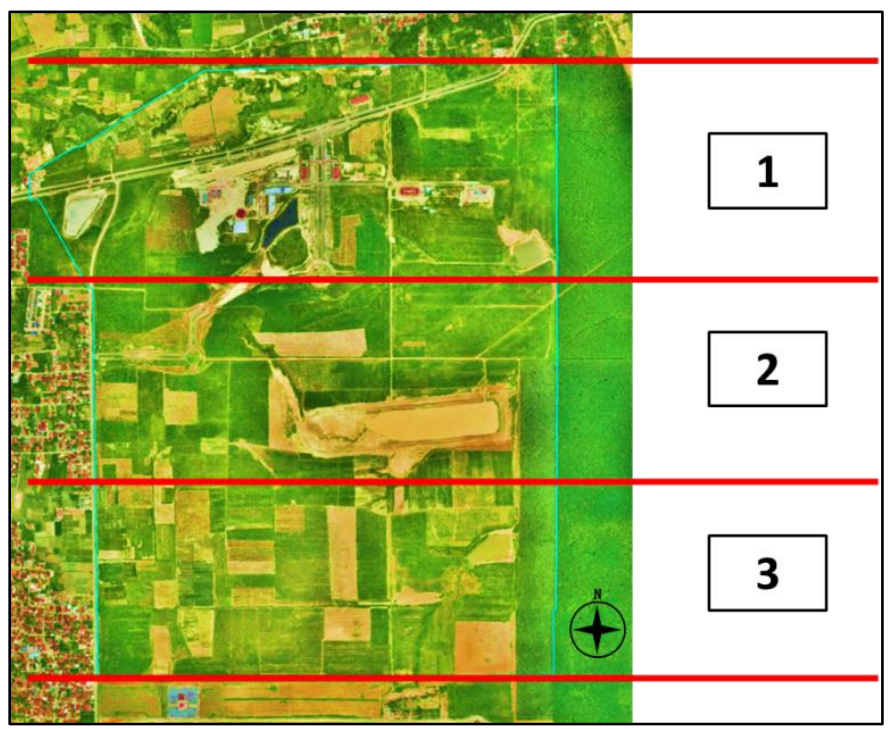

Figure 1. Research area: Land of ITERA divided into three large zones of observation.

\subsection{Environmental and plant data collection}

The research includes primary data collection used purposive random sampling method for environmental baseline analysis. Supporting data on environmental bases include wind speed, air temperature, and air humidity data. Soil conditions data studied through secondary literature. The cruising method used for sampling plant samples. The data found recorded in the observation table that has been provided and save the coordinates using GPS. Repetition of sampling carried out oddly three times with different cruising areas.

\section{Result and discussion}

\subsection{Environmental data analysis}

\subsubsection{Soil Conditions}

ITERA belongs to the South Lampung region. South Lampung is a transition zone between the hills and plains of Southern Sumatra. With silt and clay types which are categorized as light soils. The ground color will generally be brighter. This is due to the dominance of pumice, andesitic tuffs, and sandstones which are dominant in the parent rock formation. Silt is a transitional material between clay and fine sand, based on the soil fraction, silt can be classified as dust. This silt (dust) character dominates the characteristics of the lands in the South Lampung region.

\subsubsection{Climatic conditions}

The climatic conditions observed included wind speed, air temperature, and air humidity recorded by the UPT MKG ITERA during the April-June 2018 period. The data taken consists of morning climax data (06.00-09.00 WIB) and afternoon (15.00-18.00 WIB). 


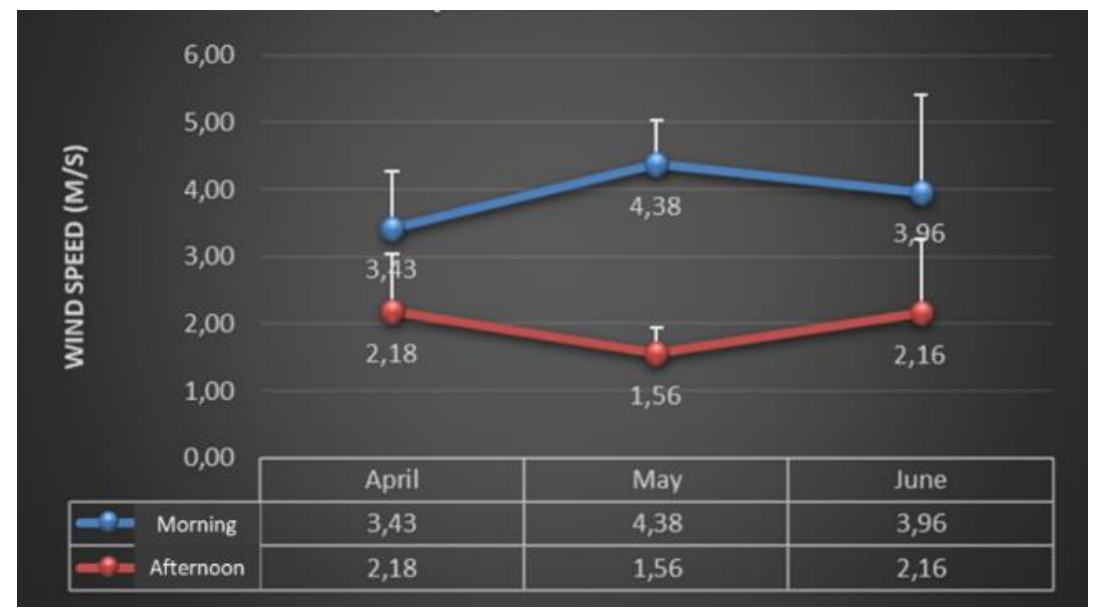

Figure 2. The calculation result of the average wind speed at ITERA during April to June 2018

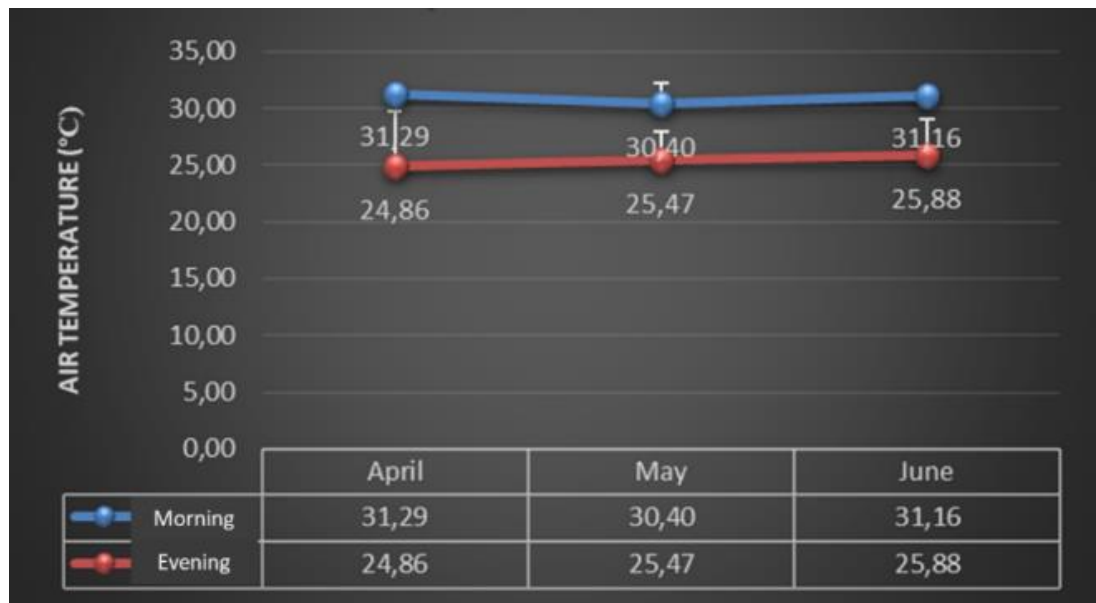

Figure 3. The calculation result of the average air temperature at ITERA during April to June 2018

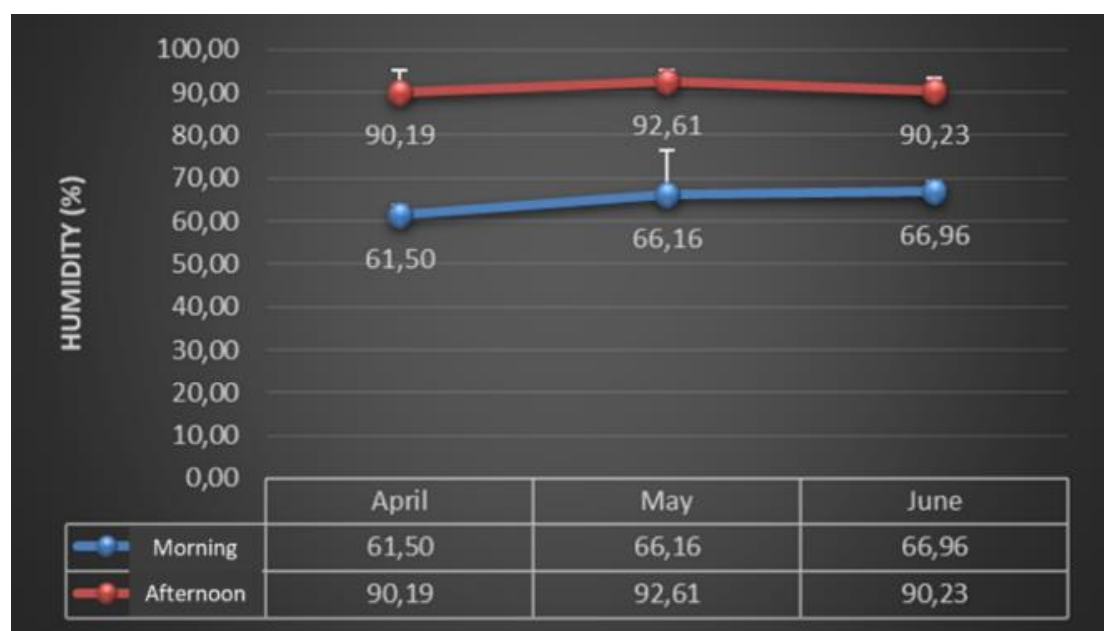

Figure 4. The calculation result of the average air humidity at ITERA during April to June 2018

Based on the result details of three climate conditions (figure 2,3, and 4), ITERA has a constant wind speed, high temperature, and high humidity level. It was affected by the sea levels and land topography. ITERA is thought to be the habitat of dry lowland forest types. Swamps formed in the basin are usually 
only flooded in the rainy season due to blockage of drainage. Regional climate data of ITERA could determine the type and the distribution pattern of plant.

\subsection{Vegetation analysis and Plant collection catalogue}

The construction of the ITERA campus area began in 2014 on an area of 298 ha. Several buildings have been built, among others: the main gate of the ITERA campus, venue, LPPM building, canteen, mosque, rector's office, public lecture building, technical laboratory, and student dormitories. A total of 6 retention basin had been built in several locations. Before being built, the ITERA was consisted of a productive rubber forest and swamps. After the land had been cleared, some part of the area that has not been used for building development turn into dry land and planted with various types of crops, especially cassava and corn (figure 5).

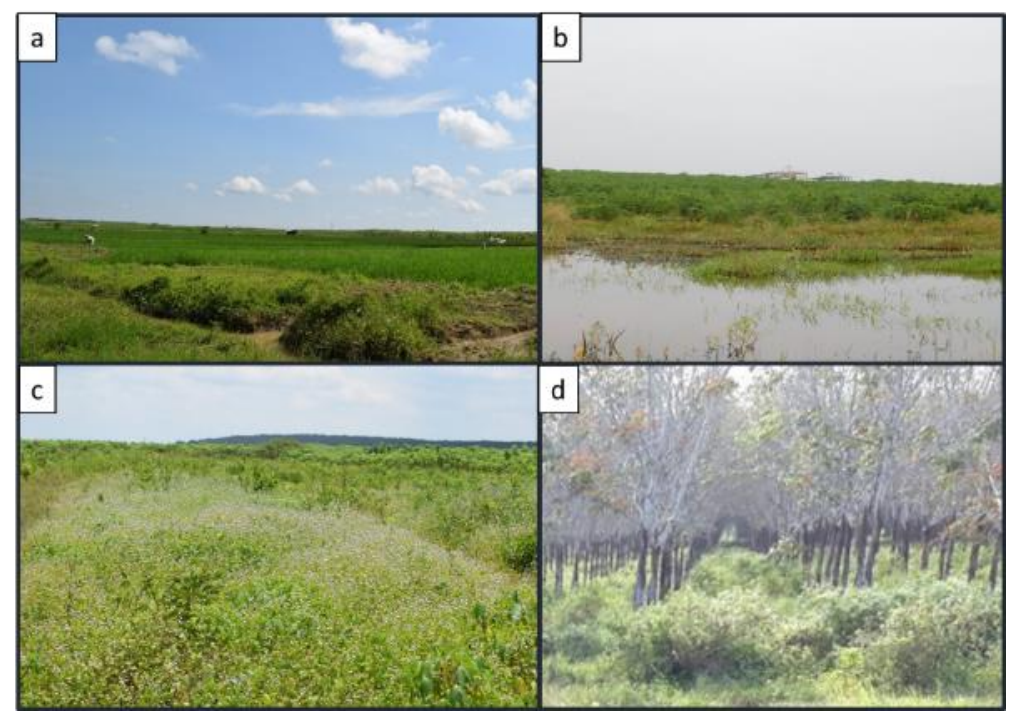

Figure 5. The condition of land development at ITERA, before and after development : a. rice field, $b$. cassava and swamp gardens, c. unprocessed land and covered with weeds and grass, $d$. former rubber plantation.

Based on the survey result, the plant data collection was divided into two categories, first for weeds/ wild plants found on crops and fallow fields, and second for shrubs, trees and palms in the ITERA campus area (Table 1 and 2).

Table 1. The list of weeds / wild plants found on crops and fallow fields.

\begin{tabular}{clll} 
No. & \multicolumn{1}{c}{ Species } & \multicolumn{1}{c}{ Famili } & \multicolumn{1}{c}{ Local name } \\
1 & Ageratum conyzoides & Compositae & Babadotan \\
2 & Asystasia gangetica & Acanthaceae & Ara sungsang \\
3 & Axonophus compressus & Poaceae & Rumput gajah \\
4 & Bidens pilosa & Compositae & Ajeran \\
5 & Borreria alata & Rubiaceae & Katumpangan \\
6 & Borreria leavis & Rubiaceae & Gempur batu \\
7 & Breynia racemosa & Euphorbiaceae & Imer \\
8 & Cassia tora & Leguminosae & Galenggang kecil \\
9 & Celosia argentea & Amaranthaceae & Jengger ayam \\
10 & Centrosema pubescens & Leguminosae & Ki besin \\
11 & Chromalomena odorata & Compositae & Ki rinyuh \\
12 & Cleome rutidosperma & Cleomaceae & Mamang \\
13 & Clibadium surinamensis & Compositae & Ki pait
\end{tabular}


ICOSITER 2018 Proceeding Journal of Science and Applicative Technology

\begin{tabular}{clll} 
No. & \multicolumn{1}{c}{ Species } & \multicolumn{1}{c}{ Famili } & \multicolumn{1}{c}{ Local name } \\
14 & Crassocephalum crepidiodes & Compositae & Sintrong \\
15 & Croton hirtus & Euphorbiaceae & Cerakin \\
16 & Cynodon dactylon & Poaceae & Grintingan \\
17 & Cyperus esculentus & Cyperaceae & Siprus \\
18 & Cyperus rotundus & Cyperaceae & Teki \\
19 & Elephantopus scaber & Compositae & Tapak liman \\
20 & Erigeron sumatrensis & Compositae & Jalantir \\
21 & Fimbristylis miliacea & Cyperaceae & Panon munding \\
22 & Heliotropium indicum & Boraginaceae & Ekor anjing \\
23 & Hyptis capitata & Lamiaceae & Lampesan \\
24 & Ludwigia hyssopifolia & Onagraceae & Cacabean \\
25 & Mikania micrantha & Compositae & Sembung rambat \\
26 & Mimosa pigra & Leguminosae & Rebah bangun \\
27 & Mimosa pudica & Leguminosae & Putri malu \\
28 & Oxalis barrelieri & Oxalidaceae & Calincing \\
29 & Phylanthus urinaria & Phyllanthaceae & Meniran \\
30 & Porophyllum ruderale & Compositae & Ketumbar bolivia \\
32 & Scoparia dulcis & Plantaginaceae & Ginje menir \\
33 & Sida acuminata & Malvaceae & sidagori \\
34 & Spigelia anthelmia & Loganiaceae & Platikan \\
35 & Stachytarpheta indica & Verbenaceae & Pecut kuda \\
36 & Stachytarpheta jamaicensis & Verbenaceae & Pecut kuda \\
\hline
\end{tabular}

In general, weeds that grow in the ITERA campus land area were types of immigrants that commonly found elsewhere. But there is one type of weed known from Sumatra, namely Erigeron sumatrensis (Compositaev). Weeds in palawija planting areas are dominated by Ageratum conyzoides, Bidens pilosa, Clibadium surinamense, Chromalomena odorata, Crassocephalum crepidiodes, Elephantopus scaber, Mikania micrantha, and Porophyllum ruderale. Fallow areas are found in several parts of the region with various types of herbs and shrubs known as pioneer plants such as Melastoma malabathricum (Melastomataceae), Sida acuminata, Urena lobata (Malvaceae), Chromalomena odorata, Elephantopus scaber (Asteraceae), Ludwigia hyssopifolia (Onagraceae), Hyptis capitata (Lamiaceae), Mimosa pudica, Mimosa pigra (Leguminosae), and Asystasia gengetica (Acanthaceae). From the results of observations when compared with the survey data in 2017 there were several plants that had been lost due to the process of clearing land for the construction area.

Table 2. The list of shrubs, trees and palms in the ITERA campus area

\begin{tabular}{clll} 
No. & \multicolumn{1}{c}{ Species } & \multicolumn{1}{c}{ Famili } & \multicolumn{1}{c}{ Local name } \\
1 & Acacia auriculiformis Benth. & Leguminosae & Akasia \\
2 & Albizia chinensis (Osbeck) Merr. & Fabaceae & Sengon putih \\
3 & Annona muricata L. & Annonaceae[ & Sirsak \\
4 & Aquilaria malaccensis & Thymelaeaceae & Gaharu \\
5 & Arenga pinnata (Wurmb) Merr. & Arecaceae & Aren \\
6 & Breynia racemosa (Blume) Müll.Arg. & Phyllanthaceae & Imer \\
7 & Caryota mitis Lour. & Arecaceae & Saray \\
8 & Casuarina equisetifolia & Casuarinaceae & Cemara laut \\
9 & Durio zibethinus & Malvaceae & Durian \\
10 & Enterolobium cyclocarpum (Jacq) Grisep & Fabaceae & Sengon Merah \\
11 & Kleinhovia hospita L. & Malvaceae & Katimaga \\
12 & Melaleuca leucadendra (L.) L. & Myrtaceae & Kayu Putih \\
13 & Mimusops elengi & Sapotaceae & Tanjung
\end{tabular}




\begin{tabular}{rlll} 
No. & \multicolumn{1}{c}{ Species } & \multicolumn{1}{c}{ Famili } & \multicolumn{1}{c}{ Local name } \\
14 & Muntingia calabura L. & Muntingiaceae & Kersen, ceri \\
15 & Piper aduncum L. & Piperaceae & Ki seureuh \\
16 & Samanea saman (Jacq.) Merr. & Fabaceae & Trembesi \\
17 & Sesbania sesban (L.) Merr. & Leguminosae & Jayanti \\
18 & Swietenia macrophylla King & Meliaceae & Mahoni \\
19 & Terminalia catappa & Combretaceae & Ketapang \\
20 & Terminalia mantaly H.Perrier & Combretaceae & Ketapang \\
21 & Trema orientalis (L.) Blume & Cannabaceae & Anggrung \\
\hline
\end{tabular}

Some species of trees or shrubs that grow naturally on ITERA site are only secondary or pioneer species which are also often found elsewhere, especially on open land or degraded forests. These types of plants include: Trema orientalis (L.), Blume (Cannabaceae), Breynia racemosa (Blume) Müll.Arg. (Phyllanthaceae), Kleinhovia hospita L. (Malvaceae), and Piper aduncum L. (Piperaceae). The type of palm encountered was Arenga pinnata (Wurmb) Merr. and Caryota mitis Lour. allegedly also intentionally allowed to grow naturally on the site. Both types are often found grow and adapt well on open land to closed forests. Muntingia calabura L. (Muntingiaceae) tree species or shrubs that are commonly known as grubby or more popularly cherry, is a migrants and often found in urban areas. The rest of the original forest ecosystem were no longer found at ITERA.

\section{Conclusion}

Based on the results and discussion there were 36 species of weeds/wild plants found on crops and fallow fields and 21 species of shrubs, trees and palms within the land of ITERA. After this study, we need to analyse correlation between the plant vegetation and animal diversity such as bird and insect to avoid habitat loss and fragmentation during land development and construction of facilities at ITERA.

\section{Acknowledgement}

This work is financially supported by Institut Teknologi Sumatera under Research Grant for Hibah Mandiri ITERA 2018.

\section{References}

[1] Hortal, J., K. A. Triantis, S. Meiri, E. Thebault, dan S. Sfenthourakis. (2009). Island species richness increased with habitat diversity. American Naturalist 174: E205-E217.

[2] Stein, A., K. Gerstner, dan H. Kreft. (2014). Environmental heterogeneity as a universal driver of species richness across taxa, biomes and spatial scales. Ecology Letters 17:866-880.

[3] Pausas, J. G., dan M. P. Austin. (2001). Patterns of plant species richness in relation to different environments: an appraisal. Journal of Vegetation Science 12:153-166.

[4] Eken G, Bennun L, Brooks TM, Darwall W, Fishpool LD, Foster M, et al. Key biodiversity areas as site conservation targets. Bioscience. 2004; 54: 1110-8.

[5] Reese GC, Wilson KR, Flather CH. Performance of species richness estimators across assemblage types and survey parameters. Glob Ecol Biogeogr. 2014; 23: 585-94.

[6] McKinney, M. L. (2008). Effects of urbanization on species richness: a review of plants and animals. Urban Ecosystems 11:161-176.

[7] Vitousek, P. M., H. A. Mooney, J. Lubchenco, dan J. M. Melillo. (1997) Human domination of earth's ecosystems. Science 277:494-499. 